\title{
Laras Desa: Rancangan Konsep Media Komunitas Pemberdayaan Keluarga
}

\section{Laras Desa: A Concept Design of Community Media for Family Empowerment}

\author{
Irfan Dhiya Alaudin*1, Adi Nur Vianto ${ }^{2}$, Aldoni Pratama Susanto ${ }^{3}$, Fadil Rizqi \\ Pangestu $^{4}$, Giwang Eka Risti ${ }^{5}$, Annis Azhar Suryaningtyas ${ }^{6}$ \\ Program Studi Ilmu Komunikasi, Universitas Muhammadiyah Magelang \\ *Penulis korespondensi
}

\begin{abstract}
1irfandhiya531@gmail.com, ${ }^{2}$ adinur1411@gmail.com, ${ }^{3}$ aldonipratama16@gmail.com, vhadhilrizqee@gmail.com, ${ }^{5}$ teamwang.15@gmail.com, ${ }^{6}$ annis.azhar@ummgl.ac.id
\end{abstract}

Riwayat Artikel: Dikirim 6 April 2021; Diterima 6 Mei 2021; Diterbitkan 31 Mei 2021

\begin{abstract}
Abstrak
Pemberdayaan Kesejahteraan Keluarga (PKK) merupakan wadah keterlibatan perempuan dalam pembangunan utamanya dalam pemberdayaan keluarga. Namun demikian, terdapat hambatan dalam proses regenerasinya. Oleh sebab itu, Pemerintah Kabupaten Magelang membuat program inovatif dengan membentuk PKK Milenial. Salah satu tujuan PKK Milenial melaksanakan inovasi dan percepatan terhadap kegiatan pemberdayaan keluarga. Hal ini sejalan dengan peran dari media komunitas dalam mengawal pembangunan untuk pemberdayaan masyarakat. Pemanfaatan media komunitas belum banyak digunakan sebagai sarana pemberdayaan keluarga dan masyarakat, seperti halnya di Kecamatan Tempuran. Sementara itu, adanya media komunitas pada dasarnya dapat menjadi saluran penyampaian informasi yang dibutuhkan oleh warga. Menjadi forum diskusi publik. Serta membantu mencapai kesepakatan untuk mengatasi persoalan. Terakhir, menumbuhkan semangat partisipasi dalam pembangunan yang berfokus pada pemberdayaan masyarakat. Dalam penelitian ini menggunakan Pendekatan Systematic Literature Review (SLR). Yang menekankan pada pengumpukan data dan informasi fokus kepada pemanfaatan media pada komunitas PKK di Tempuran Kabupaten Magelang. Hasil dari penelitian ini adalah terciptanya Media Komunitas Laras Desa yang terinspirasi dari 10 Tugas Pokok PKK. 10 Tugas pokok tersebut diturunkan menjadi poin-poin utama pada konten Laras Desa yang meliputi informasi-informasi seputar isu pendidikan, kesehatan, lingkungan, sosial budaya, ekonomi, dan hiburan yang dibuat dan dibutuhkan oleh masyarakat mitra.
\end{abstract}

Kata kunci: Media komunitas, pemberdayaan keluarga, PKK milenial Tempuran, Systematic Literature Review (SLR), Laras Desa.

\begin{abstract}
Family Welfare Empowerment (PKK) is a forum for women's involvement in the main development of the family empowerment. However, there are obstacles in the regeneration process. Therefore, the Magelang Regency Government made an innovative program by forming the Millennial Family Welfare Empowerment. One of the goals of the Millennial Family Welfare Empowerment is to implement innovation and accelerate family empowerment activities. This is in line with the role of community media in guarding development for community empowerment. The use of community media has not been widely used as a means of empowering families and communities., as in Tempuran District. Meanwbile, the existence of community media can basically be a channel for delivering information needed by citizens. Become a public discussion forum. As well as helping to reach an agreement to solve the problem. Finally, fostering a spirit of participation in development that focuses on community empowerment. In this study using a Systematic Literature Review (SLR) approach. Those who emphasize the collection of data and information focus on the use of media in the PKK community in Tempuran, Magelang Regency. The result of this research is the creation of "Laras Desa" Community Media, which is inspired by the 10 Main Tasks of the PKK. These 10 main tasks are broken down into main points in the "Laras Desa" content, which includes information on issues of education, health, environment, socio-culture, economy, and entertainment created and needed by partner communities.
\end{abstract}

Keywords: Community Media, Family Empowerment, Tempuran Milennial, Family Welfare Empowerment, Systematic Literature Review (SLR), Laras Desa 


\section{PENDAHULUAN}

Pemberdayaan Kesejahteraan Keluarga (PKK) merupakan wadah keterlibatan perempuan dalam pembangunan $\mathrm{Hal}$ itu dijabarkan pada 10 Program Pokok PKK meliputi Penghayatan dan Pengamalan Pancasila, Gotong Royong, Pangan, Sandang, Perumahan dan Tatalaksana Rumah Tangga, Pendidikan dan Keterampilan, Kesehatan, Pengembangan Kehidupan Berkoperasi, Kelestarian Lingkungan Hidup, dan Perencanaan Sehat. Namun demikian, keterlibatan anggota PKK belum bisa maksimal. Perempuan cenderung pasif ketika berada dalam forum formal. Minat perempuan untuk berpartisipasi dalam kegiatan PKK pun masih perlu ditingkatkan (Administrator, 2s018). Oleh karenanya, PKK mengalami kendala dalam regenerasi kepengurusan (PKK MILLENNLAL (Pemberdayaan Kesejabteraan Keluarga) Millennial, 2020).

Menyikapi hal tersebut, Pemerintah Kabupaten Magelang membuat program inovatif dengan membentuk PKK Milenial. PKK Milenial bertujuan melakukan sosialisasi dan pendekatan kepada anak muda terkait dengan program-program yang dilakukan oleh Tim Penggerak PKK Kabupaten Magelang (Rohmadi, 2020). Tujuan lainnya ialah memudahkan dalam regenerasi struktur kepengurusan PKK, mewadahi partisipasi pemuda-pemudi dalam pembangunan, serta melaksanakan inovasi dan percepatan terhadap kegiatan pemberdayaan keluarga. Kemudian, manfaat yang diharapkan dari pembentukan PKK Milenial pertama ialah tergalinya informasi potensi-potensi yang ada di desa. Kedua, tumbuhnya minat dan kepedulian pemuda dan pemudi terhadap pembangunan desa/kelurahan (PKK MILLENNIAL (Pemberdayaan Kesejabteraan Keluarga) Millennial, 2020).

Pembentukan PKK Milenial diteruskan hingga tingkat kecamatan dan kelurahan. Salah satu PKK Milenial yang berkembang dengan baik pada tingkat kecamatan ialah PKK Milenial Kecamatan Tempuran (Dhanik, 2021). Beberapa program telah dijalankan oleh PKK Milenial Kecamatan Tempuran. Misalnya saja, program Lapak Daring dan "Pengangguran sukses". Dengan segudang potensi yang dimiliki Kecamatan Tempuran, sayangnya masih belum ada sebuah inovasi yang fokus pada menyalurkan informasi yang secara khusus menggali tentang potensi dan isu-isu lokal di Kecamatan Tempuran yang dapat menunjang pembangunan dalam bidang pemberdayaan keluarga. Sementara, inovasi tersebut perlu diterapkan PKK Milenial Kec. Tempuran sebagai wujud inovasi dan percepatan terhadap kegiatan pemberdayaan keluarga serta tergalinya informasi potensi-potensi yang ada di desa.

Media komunitas merupakan media yang dikelola oleh komunitas tertentu. Berita yang diangkat oleh media komunitas merupakan informasi-informasi yang dibutuhkan dan dekat dengan komunitas tersebut. Selain itu, media komunitas juga memiliki peran dalam proses pembangunan. Oleh karenanya media komunitas dapat dirancang sebagai saluran penyampaian informasi dari warga dan untuk warga untuk memperkuat pemberdayaan keluarga. Sebabnya media komunitas dapat bermanfaat sebagai, penyedia informasi, forum diskusi publik, ruang diskusi untuk mencapai kesepakatan, dan sarana partisipasi warga dapat menjadi tawaran solusi sebagai bentuk inovasi dan percepatan terhadap pada program pembangunan pemberdayaan keluarga. Dengan demikian maka, perancangan media komunitas di kecamatan Tempuran penting untuk diaktifkan sebagai salah satu pilar penunjang kesuksesan pembangunan pemberdayaan keluarga.

\section{METODE}

Metode penelitian yang digunakan dalam penelitian ini adalah dengan Pendekatan Systematic Literature Review (SLR). Systematic 
Literature Review (SLR) adalah metodologi penelitian atau riset tertentu dan pengembangan yang dilakukan untuk mengumpulkan serta mengevaluasi penelitian yang terkait pada fokus topik tertentu (Triandini et al., 2019)

Gambar 1: Launcing Lapak Daring
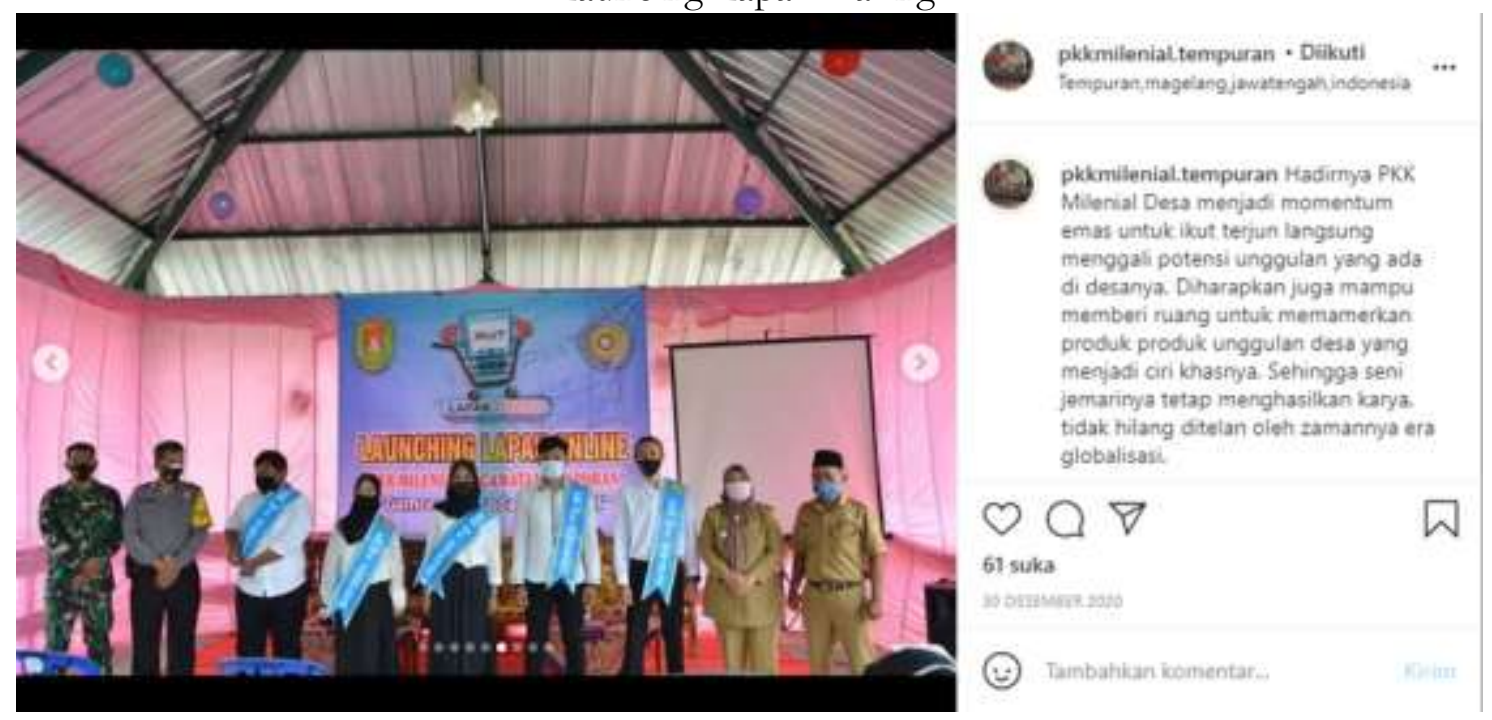

\section{HASIL DAN PEMBAHASAN}

Pada tahun 2019 Tim Penggerak PKK Kabupaten Magelang membentuk embrio PKK Milenial. Hal ini dilatarbelakangi oleh adanya kendala dalam regenerasi kepengurusan PKK. Sebab belum siapnya kader pengganti. PKK Milenial disahkan melalui Surat Keputusan Ibu Ketua Tim Penggerak PKK Kabupaten Magelang. PKK Milenial dibentuk pada tingkat kecamatan hingga kelurahan (PKK MILLENNIAL (Pemberdayaan Kesejabteraan Keluarga) Millennial, 2020). PKK Milenial menjadi program unggulan dalam rangka penilaian Penghargaan Pembangunan Daerah (PDD) 2021 (Prihantoro, 2021). PKK Milenial dibentuk setidaknya dengan tiga tujuan. Pertama, memudahkan dalam regenerasi struktur kepengurusan PKK. Kedua, mewadahi partisipasi pemudapemudi dalam pembangunan. Ketiga, melaksanakan inovasi dan percepatan terhadap kegiatan pemberdayaan keluarga. Sementara itu, PKK Milenial diharap dapat memberi manfaat di antaranya ialah tergalinya informasi potensi-potensi yang ada di desa (PKK MILLENNIAL (Pemberdayaan Kesejabteraan Keluarga) Millennial, 2020).

PKK Milenial di Kecamatan Tempuran terbentuk pada Agustus 2020. PKK Milenial Kecamatan Tempuran menjadi salah satu PKK Milenial Kecamatan yang sudah berkembang dengan baik. Terdapat beberapa program unggulan, di antaranya ialah Lapak Daring, Pembentukan Pojok Baca Milenial, "Pengangguran Sukses", Posyandu Remaja dan Podcast untuk diseminasi informasi secara daring di Tempuran (Dhanik, 2021).

Namun demikian, guna menunjang peran PKK Milenial dalam inovasi dan percepatan terhadap kegiatan pemberdayaan keluarga dan tergalinya informasi potensi-potensi yang ada di desa. PKK Milenial Kecamatan Tempuran masih belum memiliki konsep yang matang terkait dengan media untuk menyampaikan informasi berbasis daring. Sementara akses informasi yang sesuai kebutuhan masyarakat 
dapat digunakan sebagai sumber pembangunan masyarakat dan pemberdayaan keluarga. Misalnya saja, belum tampak adanya publikasi yang memuat potensi unggulan kecamatan Tempuran. Contoh, tentang Usaha Mikro Kecil dan Menengah (UMKM) di Kecamatan Tempuran, program inovatif kecamatan Tempuran seperti Lapak Daring dan "Pengangguran Sukses", program kesehatan, dll. Bisa jadi, informasi terkait akses atau kepesertaan warga bergabung dalam inovasi dibutuhkan oleh warga kecamatan Tempuran kemudian dapat diterapkan bagi pemberdayaan keluarga.

Gambar 1 ialah proses peluncuran program Lapak Daring. Harapannya program ini tidak terhenti pada acara seremonial. Ada baiknya, terdapat sistem yang berasal dari warga dan untuk warga yang dapat melaporkan, memantau, dan mengevaluasi jalanannya program yang telah direncanakan. Selanjutnya, program dapat berjalan secara berkelanjutan dan dapat diaplikasikan oleh setiap warga guna terwujudnya pemberdayaan keluarga.

Gambar 2 di atas ialah pelaksanaan program Tresno Marang Tanduran. Pada publikasi kegiatan ini, belum tampak datadata tentang pelaksanaan program. Misalnya saja, isu yang melatarbelakangi dilaksanakannya program ini, tujuan program, proses pelaksanaan, atau bahkan manfaat untuk warga atas adanya program pendampingan ini. Bila mana, data-data tersebut dapat dilaporkan melalui proses jurnalistik yang komprehensif kiranya akan berdampak positif bagi pemberdayaan keluarga.

Gambar 3 display barang-barang UMKM potensial yang ada di Kecamatan Tempuran . Sedangkan gambar 4 merupakan hasil kerajinan warga dalam mengolah limbah sampah plastik menjadi barang dengan nilai ekonomis. Namun demikian, keduanya belum dapat terpublikasi dengan baik. Bila mana keterampilan tersebut dapat diulas melalui media komunitas dan diakses oleh warga lainnya besar kemungkinan dapat memberikan inspirasi dalam pemberdayaan keluarga dari sisi sosial ekonomi.

Gambar 1:

Pendampingan Program Tresno Marang Tanduran

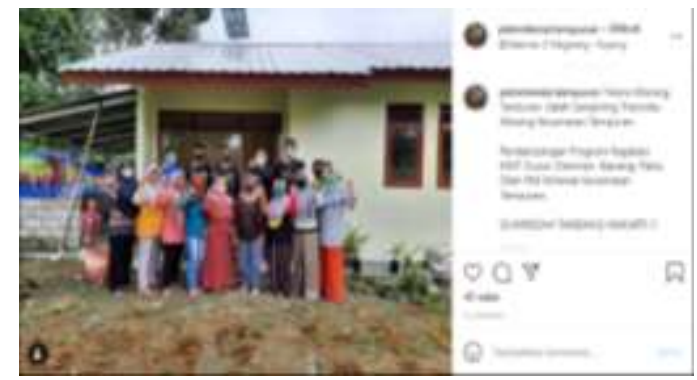

Gambar 3: Display Barang UMKM

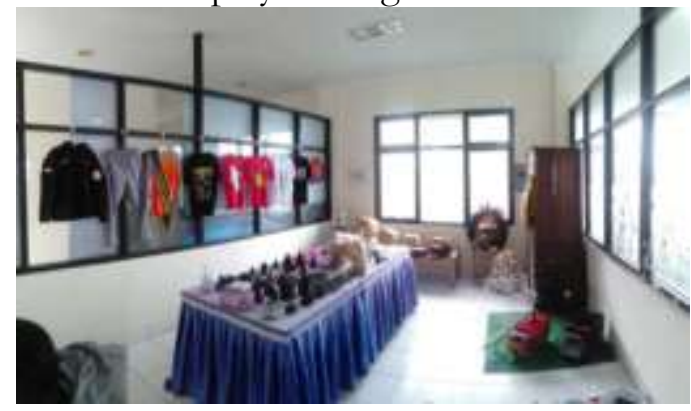

Gambar 2:

Hasil Kerajinan Warga

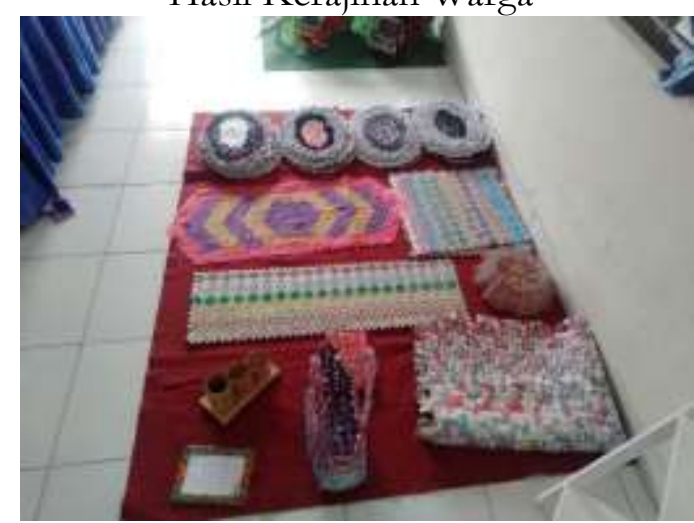

Informasi yang terkait peristiwa yang terjadi di sekitar Kecamatan Tempuran serta program-program tersebut bila disajikan di media komunitas diharap menjadi sumber informasi bagi masyarakat. Dengan 
demikian, dapat menginspirasi dan memberdayakan keluarga dari sisi sosial, pendidikan, ekonomi, kesehatan, lingkungan, dan budaya. Media komunitas juga dapat menjadi kontrol, bila mana terdapat hambatan pada pelaksanaan program-program pemerintah. Selain itu juga menjadi wadah bagi masyarakat Kecamatan Tempuran untuk menyampaikan aspirasinya.

\section{KESIMPULAN}

Laras Desa yang hendak dirancang pada program kreativitas mahasiswa kali ini berfokus pada pengembangan media komunitas berbasis daring. Media komunitas ini nantinya berperan mendukung pembangunan dan perubahan sosial guna pemberdayaan keluarga. Oleh sebab itu, konten yang hendak dicanangkan ada pada Media Komunitas Laras Desa terinspirasi dari 10 Tugas Pokok PKK. 10 Tugas pokok tersebut diturunkan menjadi poin-poin utama pada konten Laras Desa yang meliputi informasi-informasi seputar isu pendidikan, kesehatan, lingkungan, sosial budaya, ekonomi, dan hiburan yang dibuat dan dibutuhkan oleh masyarakat mitra.

\section{DAFTAR PUSTAKA}

Administrator. (2018). Ibu-ibu Muda Semakin Tidak Berminat Ikut PKK. PikiranRakyat.Com. https://www.pikiranrakyat.com/bandung-raya/pr01295893/ibu-ibu-muda-semakintidak-berminat-ikut-pkk-422737.

Dhanik. (2021). PKK Milenial Menjadi Inovasi Unggulan Kabupaten Magelang. Bappeda Dan Libangda Kabupaten Magelang. https://bappeda.magelangkab.go.id/ home/detail/pkk-milenial-menjadiinovasi-unggulan-kabupatenmagelang/231

PKK MILLENNLAL Pemberdayaan Kesejabteraan Keluarga) Millennial. (2020). Tuxodevation: Tutorial Exibition Display of Innovation. https:/ / tuxedovation.inovasi.litbang. kemendagri.go.id/detail_inovasi/267 15.

Prihantoro, T. (2021). PKK Milenial Program Unggulan Penilaian Penghargaan Pembangunan Daerah 2021. Berita Magelang. https://mnews.id/pkkmilenial-program-unggulanpenilaian-penghargaanpembangunan-daerah-2021/

Rohmadi, S. (2020). Mengulik Program PKK Dan PKK Milenial Kabupaten Magelang. Berita Magelang. http://beritamagelang.id/wawancara /mengulik-program-pkk-dan-pkkmilenial-kabupaten-magelang

Triandini, E., Jayanatha, S., Indrawan, A., Werla Putra, G., \& Iswara, B. (2019). Metode Systematic Literature Review untuk Identifikasi Platform dan Metode Pengembangan Sistem Informasi di Indonesia. Indonesian Journal of Information Systems, 1(2), 63. https://doi.org/10.24002/ijis.v1i2.1 916 